UDK: 617.7-007.681

Izvorni naučni rad

Primljeno: 5.3.2019.

Prihvaćeno za štampu: 31.5.2019.

Budimlić Enver

Budimlić D.

Budimlić A.

Dedić $\mathrm{H}$.

Univerzitet u Bihaću

Fakultet zravstvenih studija

enver.budimlic@gmail.com

\title{
SOCIJALNO-MEDICINSKI ZNAČAJ RANOG OTKRIVANJA \\ PRIMARNOG GLAUKOMA U OČUVANJU VIDA I PREVENCIJI NASTANKA SLJEPOĆE KAO TRAJNE KOMPLIKACIJE
}

\section{Sažetak}

Za život $i$ rad čovjeka vid ima ogromnu važnost pa i invalidnost organa vida zauzima posebno mjesto. Prema tome prevenciji i ranom otkrivanju smetnji vida koje predstavljaju moguće uzročnike slabovidnosti treba posvetiti posebnu pažnju.

Poslije prava na život, slijedi pravo čovjeka da gleda i vidi svijet oko sebe. Vid čovjeku služi ne samo kao čulo, nego i kao mogućnost komunikacije sa vanjskim svijetom.

Glaukom je oboljenje oka kod kojeg dolazi do oštećenja optičkog živca i može, ukoliko se ne liječi razultirati potpunim gubitkom vida. U oftalmologiji $i$ pored suvremene medikamentozne $i$ hirurške terapije, zauzima visoko mjesto kao uzrok slabovidnosti i sljepila.

Prema podacima Svjetske zdravstvene organizacije (WHO) glaukom se nalazi na drugom mjestu uzroka sljepoće širom svijeta i predstavlja ozbiljan problem iz razloga što su oštećenja vida ireverzibilna.

Ključne riječi: glaukom, rana dijagnostika, prevencija, liječenje. 


\section{UVOD}

Za život i rad čovjeka vid ima ogromnu važnost pa i invalidnost organa vida zauzima posebno mjesto. Činjenica da preko oka primamo oko 90 $\%$ svih utisaka, dok je na ostale čulne organe raspoređeno oko $10 \%$, dovoljno govori o njegovom značenju.

Prema tome prevenciji i ranom otkrivanju smetnji vida koje predstavljaju moguće uzročnike slabovidnosti treba posvetiti posebnu pažnju.

Pravovremeno otkrivanje smetnji vida daje više garancije za sprečavanje slabljenja vida i efikasnije provođenje preventivnih mjera radi zaštite vida. Ljudsko ponašanje otkriva stalnu spremnost da se da prednost informacijama iz čula vida, bez obzira na to šta nam stiže u sistem putem drugih čula. Očima dakle spoznajemo svijet i često se baš na osnovu tih vizuelnih spoznaja opredjeljujemo prema njemu.

Poslije prava na život, slijedi pravo čovjeka da gleda i vidi svijet oko sebe. Vid čovjeku služi ne samo kao čulo, nego i kao mogućnost komunikacije sa vanjskim svijetom.

Glaukom je oboljenje oka kod kojih dolazi do postepenog oštećenja optičkog živca stvaranjem glaukomatozne ekskavacije na glavi vidnog živca, ispada u vidnom polju, pada vidne oštrine i može, ukoliko se ne liječi razultirati potpunim gubitkom vida uslijed dugogodišnjeg djelovanja povišenog IOP-a. U oftalmologiji i pored suvremene medikamentozne i hirurške terapije, zauzima visoko mijesto kao uzrok slabovidnosti i slijepila. $(4,5)$.

Prema podacima Svjetske zdravstvene organizacije ( WHO) glaukom se nalazi na drugom mjestu uzroka sljepoće širom svijeta i predstavlja ozbiljan problem iz razloga što su oštećenja vida ireverzibilna.

Cilj ovog rada je obraditi glaukom, vrste glaukoma, postavljanje dijagnoze glaukoma, liječenje i prevencija glaukoma, kao i prikazati učestalost oboljelih od glaukoma na USK-a liječenih u Kantonalnoj bolnici „dr. Irfan Ljubijankić“ u periodu od 2008 do 2012. godine.Studija istraživanja je retrospektivnog karaktera, te je rađena kao skrining na glaukom kao oboljenje koje je dosta učestalo na našem kantonu.Željeli smo naše rezultate komparirati sa rezultatima drugih 
autora iz bližeg i šireg okruženja, te komparirati sa podatcima iz Evropskih zemalja.(1)

\section{DEFINICIJA PROBLEMA}

\subsection{Glaukom}

Glaukom ( od grč. glaukos = zelen, zbog sivozelenog odsjaja leće $\mathrm{u}$ zahvaćenom oku) je izuzetno teška, ozbiljna i dugotrajna očna bolest koja nakon određenog vremena dovodi do oštećenja očnog živca i smanjenja vida sve do sljepoće. Danas je na trećem mjestu u etiologiji sljepoće i računa se da na njega otpada $15-20 \%$ svih slijepih osoba.Prema podacima mnogih autora učestalost glaukoma u opštoj populaciji iznosi po podacima autora iz evropskih zemalja oko 34\%.Predstavlja jedan od najčešćih uzroka definitivne sljepoće u svijetu, posebno kod ljudi iznad 40 godina starosti. $(4,25)$.

Glaukom zapravo predstavlja sindrom, odnosno skup slijedećih simptoma:

- povišenje intraokularnog pritiska

- udubljenje-ekskavacija papile vidnog živca

- oštećenje vidnog polja

- pad vidne oštrine

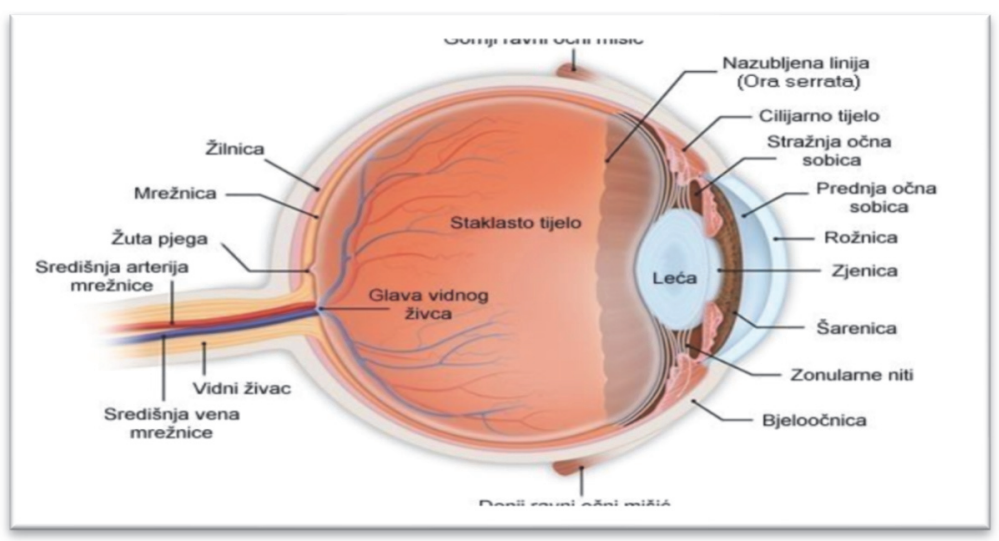

Slika 2.1. Presjek oka 
Glaukom se razvija kad je stvaranje očne vodice povećano ili je njeno oticanje otežano. Tada dolazi do porasta očnog pritiska, a samim tim i do pritiska na živćana vlakna i krvne žile optičkog živca dovodeći do njegovog oštećenja i uništavanja. Postepeno se prekida prijenos vizualne poruke do mozga, a razutat je oštećenje vida i na kraju sljepoća. Glaukom je bolest koja se ne može izliječiti, ali zahvaljujući ranom otkrivanju bolesti i odgovarajućem liječenju može se spriječiti trajni gubitak vida i kontrolisati tok bolesti.Normalne vrijednosti očnog pritiska iznose $12-22 \mathrm{~mm} \mathrm{Hg}$ (milimetara žive ). $(17,18)$

\subsection{Vrste glaukoma}

Glaukom se dijeli u tri velike osnovne skupine:

- primarni glaukom

- sekundarni glaukom

- prirođeni ( kongenitalni ) glaukom.

Kod primarnog glaukoma postoji povećanje očnog pritiska koje se ne može dovesti ni u kakvu vezu s nekom očnom ili opštom bolesti. (17).

Prema izgledu ugla prednje očne sobice ( prostor u oku između rožnice i šarenice ) primarni glaukom se dijeli na :

- primarni glaukom širokog ( otvorenog ) ugla

- primarni glaukom uskog ( zatvorenog ) ugla.

Sekundarni glaukom je povišenje očnog pritiska koje nastaje u toku neke druge očne bolesti ( stanja ) ili je posljedica iste ( npr. upale, ozljede, oštećenja i pomaci leće u oku, krvnožilne bolesti oka, šećerna bolest, tumori oka).

Prirodeni ( kongenitalni ) glaukom predstavlja rijedak oblik glaukoma koji se javlja kod djece odmah nakon rođenja ili pak u prvih nekoliko godina života.

Uzrok je postojanje zaostalog embrinonalnog tkiva u uglu prednje očne sobice.

Očna vodica ne može oticati i nastaje povišenje očnog pritiska. 
Djeca koja boluju od glaukoma imaju velik promjer rožnice (megalocornea), povećanje očne jabučice (buftalmus), zamagljen vid i preosjetljivost na svjetlost (fotofobija), a pojačano je i suzenje očiju.

Simptomi ovog oblika glaukoma ne moraju se pojaviti do 6 mjeseci ili godinu dana nakon rođenja.

Ukoliko se poremećaj ne uoči na vrijeme, kod djeteta se može javiti znatan gubitak vida ili pak sljepilo.

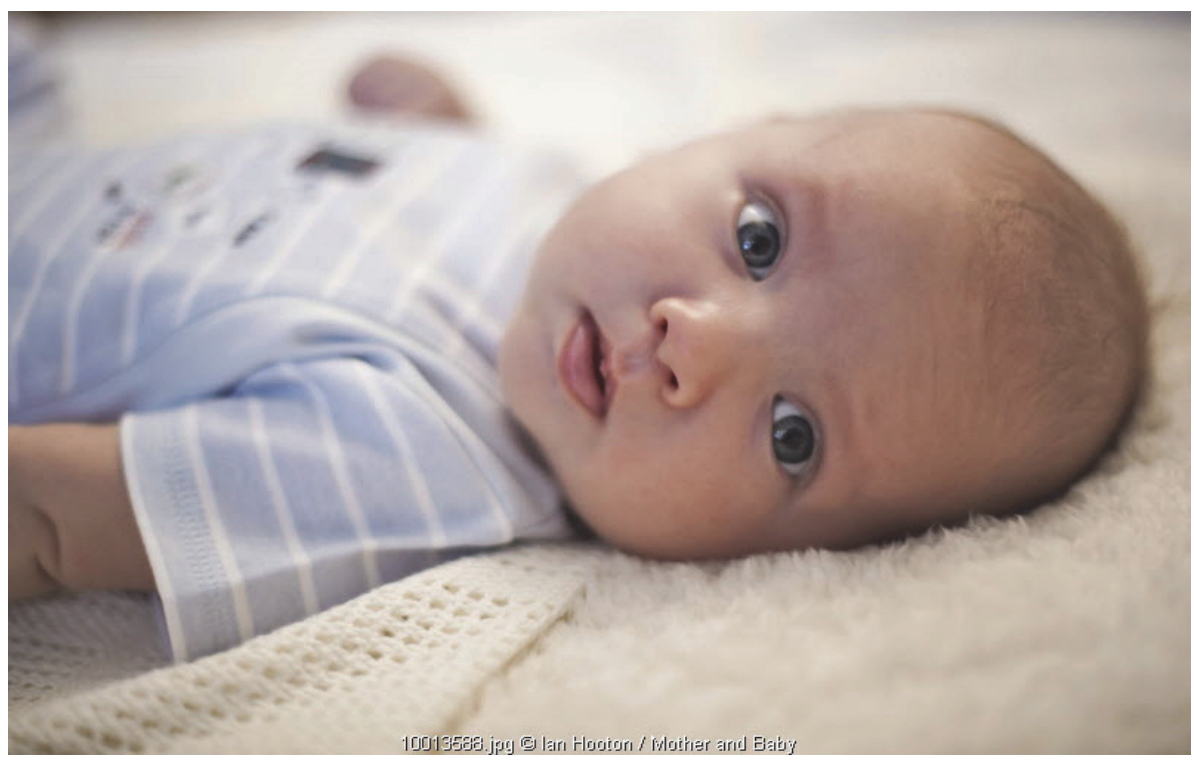

Slika 2.3. Kongenitalni glaukom

\subsubsection{Primarni glaukom otvorenog ugla}

Glaukom otvorenog ugla predstavlja najčešći oblik ove bolesti te čini više od 90 posto svih slučajeva glaukoma. Najčešće se javlja u srednjoj životnoj dobi, a postoji i vjerojatnost da je djelomice i genetski uvjetovan. Kod glaukoma otvorenog ugla oštećenje optičkog živca odvija se vrlo sporo i postupno, prvo pogađa periferni vid, no s vremenom može dovesti i do sljepoće. Obično se ljavlja u oba oka istovremeno, no često je u jednom oku izraženiji nego u drugome. Opasnost je tim veća zbog toga što centralni vid, kojim se služimo kod čitanja i uočavanja detalja, biva zahvaćen tek na kraju, pa tako bolest 
može uznapredovati prije nego što oboljele osobe primjete bilo kakve znakove oboljenja.

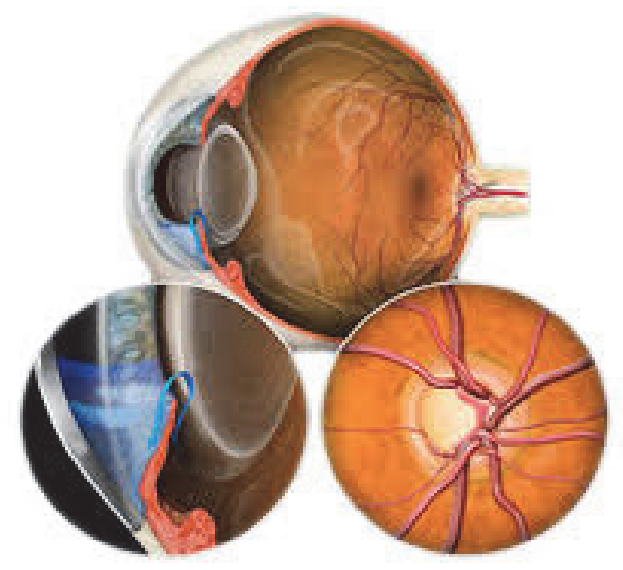

Slika 2.2.1. Primarni glaukom otvorenog ugla

Tačan uzrok nastanka oštećenja optičkog živca nije u potpunosti poznat. Očna vodica ne može normalno oticati trabekularnim sustavom, pa se nakuplja u oku i uzrokuje povišen intraokularni pritisak . Kod ovog tipa glaukoma se iz nepoznatog razloga sa godinama povećava otpor oticanju očne vodice i očni pritisak konstantno raste.

Porast očnog pritiska je umjeren u početku, a kasnije može doseći visoke vrijednosti ( $60 \mathrm{~mm} \mathrm{Hg}$ ). S vremenom strada optički živac i udubljuje se papila optičkog živca ( mjesto na kojem optički živac napušta oko).

Ispadi vidnog polje se pojavljuje vrlo rano, ispadi se šire od preiferije prema središtu pa bolesnici imaju suženo vidno polje, gledaju kao kroz dvocjevku ili tunel. Završetak procesa je sljepilo.

Primarni glaukom otvorenog ugla je podmukla bolest koja dugo vremena može biti bez simptoma ili s vrlo malo nekarakterističnih simptoma ( npr. nejasne glavobolje).

Bolest kao dijabetes melitus, vaskulopatije, hipertenzija dodatni su rizični faktori za pogoršanje prognoze, a osobito su ugrožene osobe s 
obiteljskom povješću glaukoma. Ova bolest zahvaća podjednako oba spola.

Ispadi vidnog polja se ne mogu liječiti. Liječenjem se postiže normalizacija očnog pritiska i eventualno daljnje propadanje vidnih funkcija.

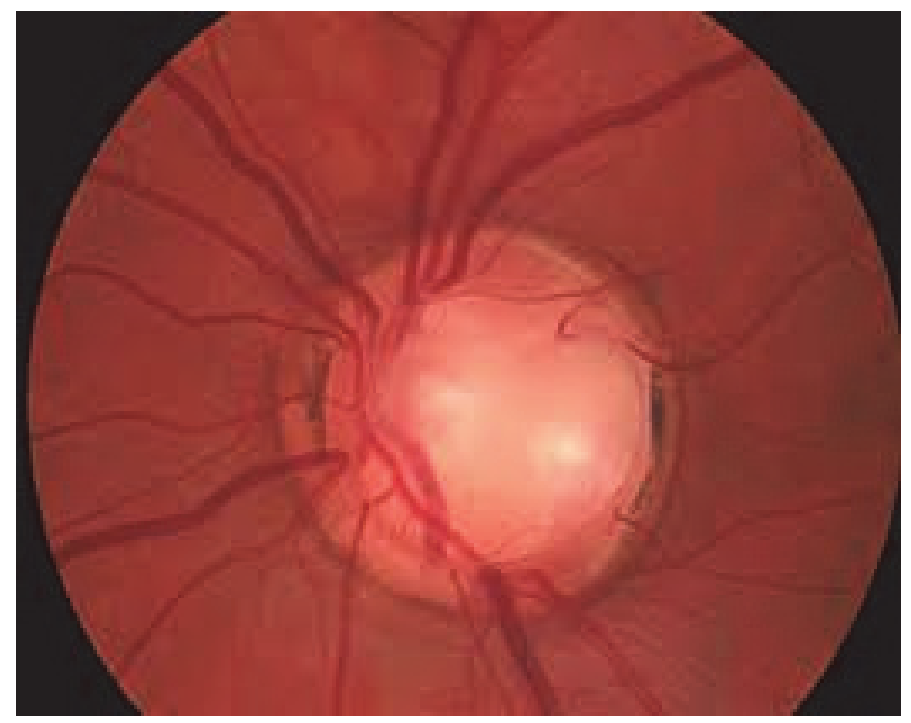

Slika 2.4. Glaukomska ekskavacija
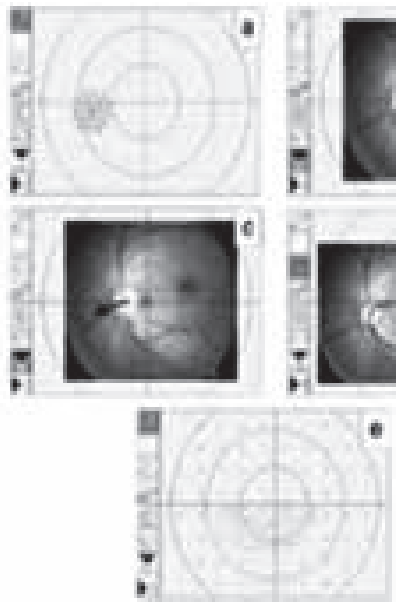

Slika 2.5. Ispadi vidnog polja

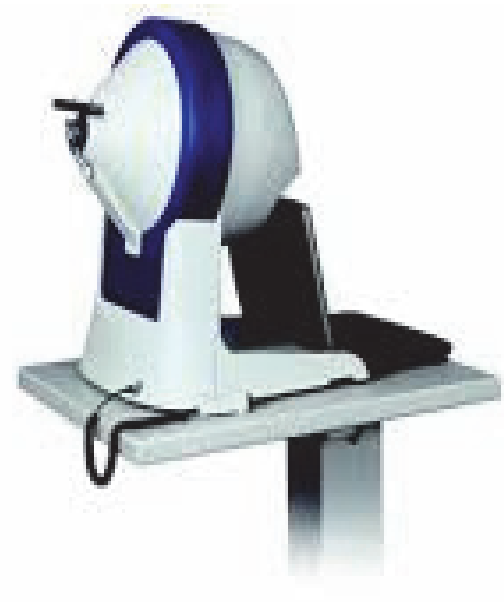

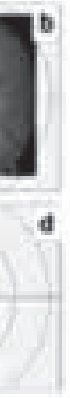

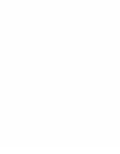




\subsubsection{Primarni glaukom zatvorenog ugla|}

Primarni glaukom zatvorenog ugla je uzrokovan kontakom između irisa oka i trabekularne mreže odnosno opstrukcijom sobičnog ugla tkivom irisa što utiče na normalno istjecanje očne vodice iz oka. Predstavlja manje zastupljen oblik glaukoma (manje od 10 posto registriranih slučajeva glaukoma). Zapreka oticanju očne vodice može biti nagla (akutna), povremena (intermitentna) ili dugotrajna (kronična). Pojavljuje se iznenada i s vrlo intenzivnom boli, uglavnom u jednom oku, no kod otprilike 50 posto oboljelih bolest se razvija i u drugom oku unutar pet godina.

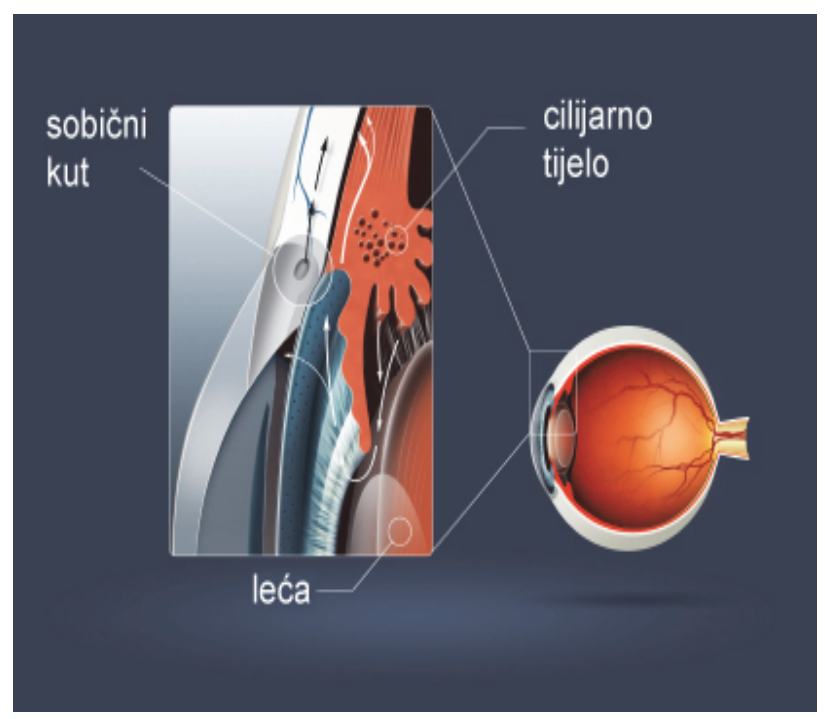

Slika 2.6. Primarni glaukom zatvorenog ugla

Akutna manifestacija glaukoma zatvorenog ugla zahtijeva hitnu liječničku pomoć. Manifestira se jako burno. Naizgled zdrav čovjek za kratko vrijeme postaje težak bolesnik, s jakim bolovima u jednom oku i licu, pojavom duginih boja oko izvora svjetlosti, glavoboljom, mučninom i povraćanjem, ali dramatičnim ,,padom vida“.(27)

Očni pritisak raste i do $80 \mathrm{~mm} \mathrm{Hg}$, oko je crveno, i na dodir tvrdo kao kamen. Ukoliko se očni pritisak ne snizi unutar nekoliko sati pomoću lijekova ili operativnog zahvata može doći do ozbiljnih i trajnih oštećenja vida. Glaukomski napadaji mogu biti slabiji i češće se ponavljati. 
Hronična manifestacija glaukoma zatvorenog ugla obično nastaje kao posljedica učestalih neliječenih glaukomskih napadaja i posljedičnih priraslica (ožiljaka) u uglu prednje sobice. Očni je pritisak stalno povišen, razvija se udubljenje i propadanje papile očnog živca $\mathrm{s}$ ispadima vidnog polja, te konačno nastaje sljepoća.

\subsubsection{Apsolutni glaukom}

Ovaj naziv označava slijepo oko. Sljepoća može nastati kao posljedica svih oblika glaukoma i označava završni stadij njegova napredovanja. Oko tada može biti izrazito bolno.

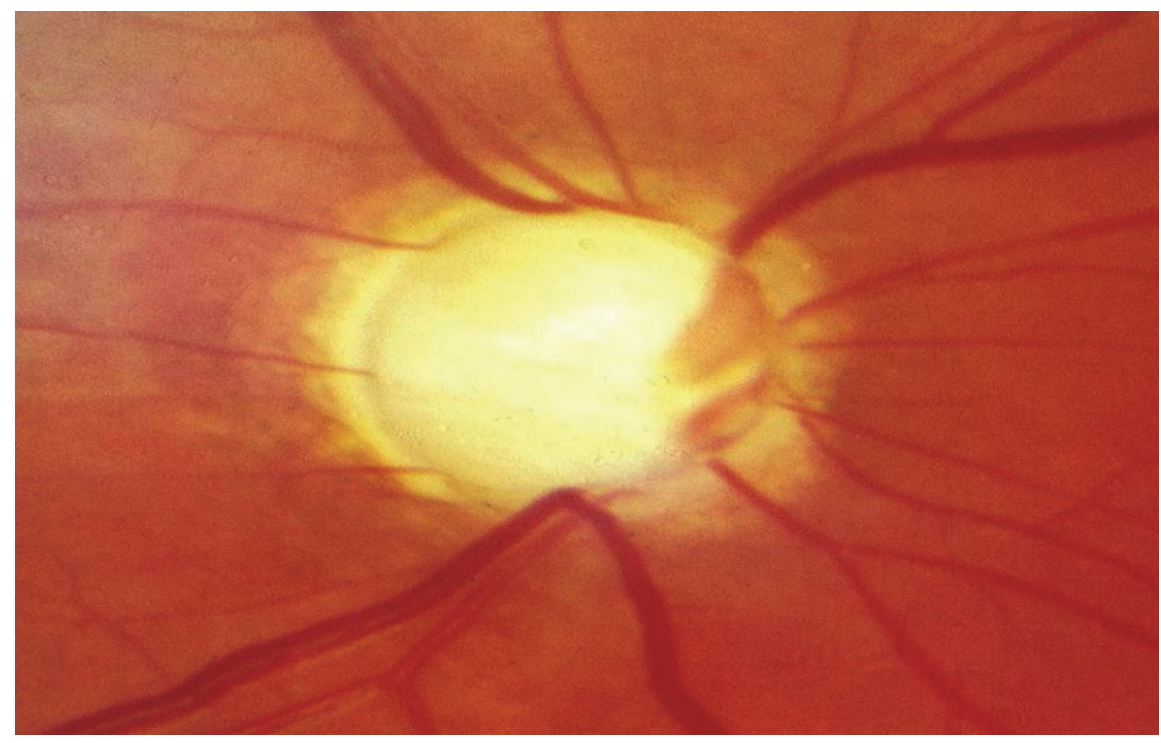




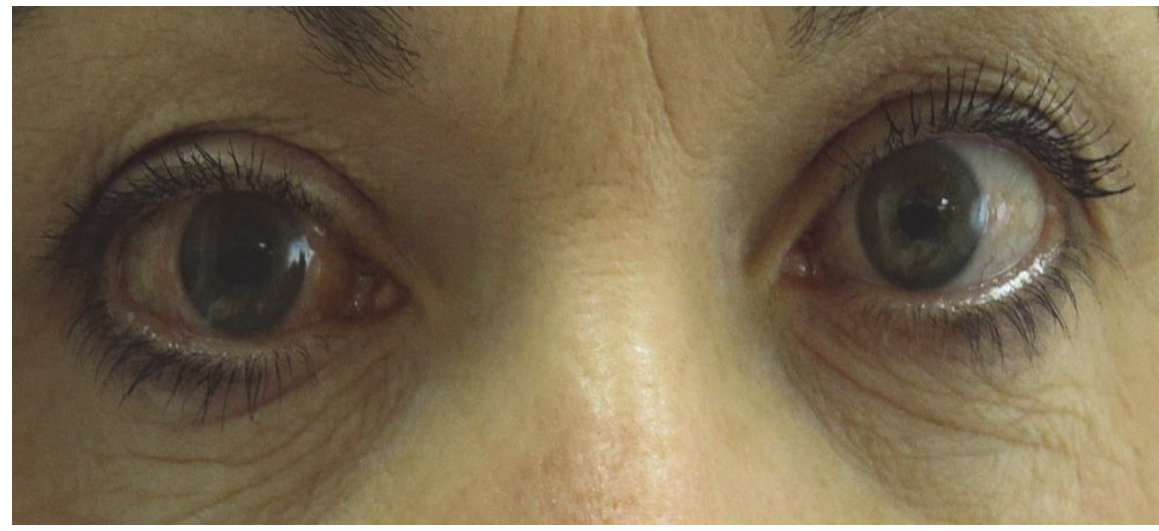

Slika 2.7. Apsolutni glaukom

(preuzeto sa:bs.wikipedia.org. i wiki.canswers.net)

\subsection{Dijagnoza glaukoma}

Nakon razgovora s pacijentom i uzete anamneze obavlja se pregled oka i dijagnostičke pretrage . Neophodno je u toku pregleda saznati je li neko od obitelji ili rođaka bolovao ili boluje od glaukoma.

Pretrage koje se obavljaju su:

- biomikroskopija (pregled oka procjepnom svjetiljkom),

- oftalmoskopija (pregled unutrašnjih struktura oka, koji pokazuje, za glaukom tipične promjene na očnom živcu),

- tonometrija (mjerenje očnog pritiska)

- određivanje vidnog polja (periferni i centralni vid) $\mathrm{i}$

- gonoskopija ( leća koja se postavlja na oko kako bi se vidjelo stanje očnog ugla).

- OCT

Pregled za dijagnosticiranje glaukoma vrlo je kratak. Liječnik će izmjeriti očni pritisak uz pomoć nekontakne tonometrije, prilikom koje instrumentom ispuhuje zrak prema očnoj jabučici. Očni pritisak mjeri se u milimetrima žive ( $\mathrm{mm} \mathrm{Hg}$ ), a normalan očni pritisak je između 12 i $22 \mathrm{~mm} \mathrm{Hg}$. Ukoliko imate povišen očni pritisak, to ne mora značiti da ste oboljeli od glaukoma. Vaš liječnik neće dijagnosticirati glaukom ukoliko ne postoji oštećenje očnog živca. 


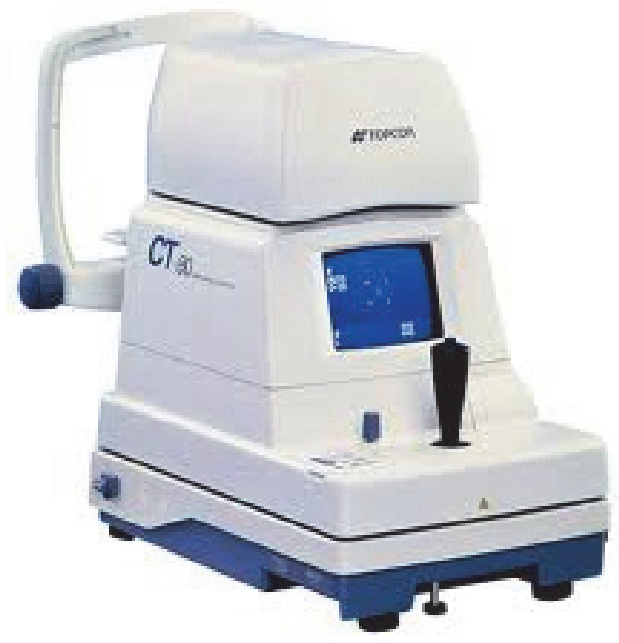

Slika 2.7. Nekontaktni zračni

tonometar

Blago povišen očni pritisak naziva se očna hipertenzija i može se regulisati i kontrolisati redovnim liječničkim pregledima. Liječnik također može obaviti testiranje širine vidnog polja, što je najbolji način ranog otkrivanja znakova gubika perifernog vida. Iako i hronični i akutni glaukom uzrokuju sljepilo, simptomi su im vrlo različiti.

Kod glaukoma otvorenog ugla ili hroničnog glaukoma,gubitak vida nastaje vrlo sporo i potpuno bezbolno tako da mnogi ljudi uopće ne primjete bilo kakav problem dok bolest već nije uznapredovala. Kod ovog oblika glaukoma prvo dolazi do gubitka perifernog vida, uznapredovala bolest može dovesti do toga da vidite samo ono što je pred vama, kao da gledate kroz tunel. Ukoliko se ne liječi, s vremenom i takav sužen vid postupno nestaje i dolazi do potpunog sljepila. Jednom kad se vidno polje izgubi, nemoguće ga je povratiti.

Najčešći simptomi hroničnog glaukoma su povremene glavobolje, zamagljen vid, te postepen gubitak perifernog vida i pojava slijepih tačaka, mjesta u vidnom polju u kojima uopšte ne vidite.

Simptomi akutnog glaukoma zatvorenog ugla znatno su intenzivniji i pojavljuju se iznenada. Uključuju iznenadnu pojavu snažne, pulsirajuće boli u samom oku ili neposrednoj blizini oka. Takođe se javlja zamagljivanje vida, pojava duginih boja oko izvora svjelosti, crvenilo i nadraženost očiju, a ponekad i mučnina i povraćanje. 
Kod urođenog glaukoma u novorođenčadi i djece kao najčešće simpome moguće je primjetiti suzne i zamagljene oči, osljetljive na svjetlost (fotofobija). Oči djeteta mogu izgledati veće zbog povećanja očne jabučice (buftalmus) uzrokovanog visokim očnim pritiskom. Ovakva promjena se ne pojavljuje kod odraslih. Ukoliko pati od glaukoma, dijete može često trljati oči, škiljiti ili ih pak većinu vremena držati zatvorenima.

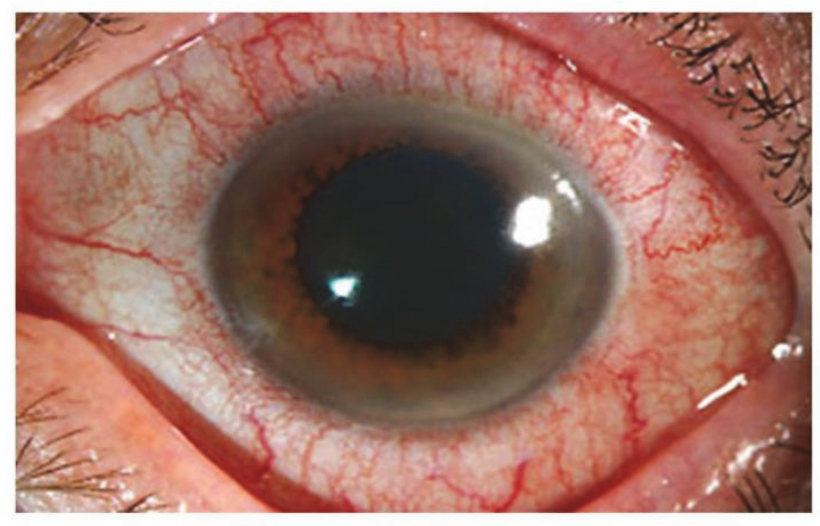

Slika 2.8. Akutni napad glaukoma

\subsection{Liječenje i prevencija glaukoma}

\subsubsection{Liječenje glaukoma}

Liječenje glaukoma obuhvata različite postupke kontrolisanja produkcije i odvođenja očne vodice iz oka, čime se očni pritisak spušta na normalni nivo i sprečava se daljnje oštećenje optičkog živca. Iako oštećenje optičkog živca može nastupiti pri bilo kojoj vrijednosti očnog pritiska, snižavanje pritiska može pomoći u zaštiti optičkog živca od daljnjeg oštećenja.

Načini liječenja glaukoma su:

- Konzervativnom terapijom ( medikamentozna terapija ),

- Klasičnim hiruškim pristupom ( hiruški zahvat ) i

- Laserom ( laserska hirurgija). 
Način liječenja gaukoma uveliko ovisi o ozbiljnosti situacije, te koliko je bolest uznapredovala.Hronični glaukom se vrlo teško dijagnosticira u ranoj fazi, no jednom kad se otkrije, može se uspješno kontrolisati. Liječenje u pravilu počinje lijekovima, no u slučaju da lijekovi ne uspiju sniziti očni pritisak, pristupa se liječenju laserom ili hiruškim zahvaom.

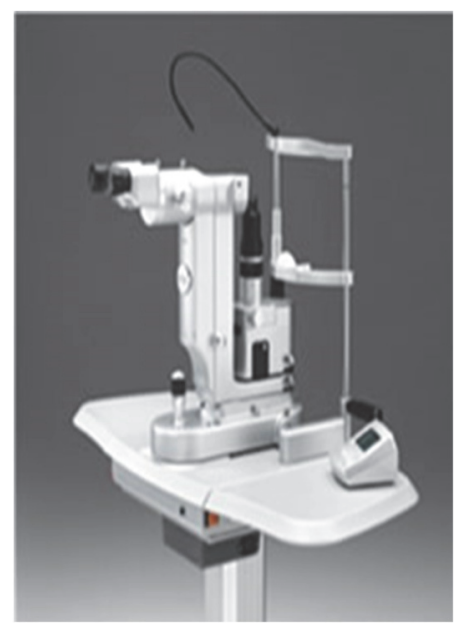

Slika 2.9. Argon laser

Konzervativno liječenje glaukoma ( medikamentozna terapija) svodi se na snizavanje očnog pritiska kao vodećeg rizičnog faktora nastanka oštećenja živca različitim lijekovima kao što su:

- Beta blokatori,

- Adrenergični agonisti,

- Inhibitori karboanhidraze,

- Kolinergični agonisti i

- Prostaglandini

Kod hroničnog glaukma liječenje uglavnom započinje prepisivanjem kapi za oči. Budući da kapi za oči mogu uzrokovati određene nuspojave ili međudjelovanje s drugim lijekovima, liječnik mora biti upoznat s mogućim drugim lijekovima koji se u tom trenutku uzimaju. Ukoliko lijčenje kapima ne pokaže razultate, liječnik može preporučiti hiruški zahvat ili terapiju laserom.

Najčešći hiruški zahvati prilikom liječenja glaukoma su: 
- Trabekulektomija ( odstranjivanje dijala trabekuluma) i

- Iridektomija ( uklanjanje dijela irisa).

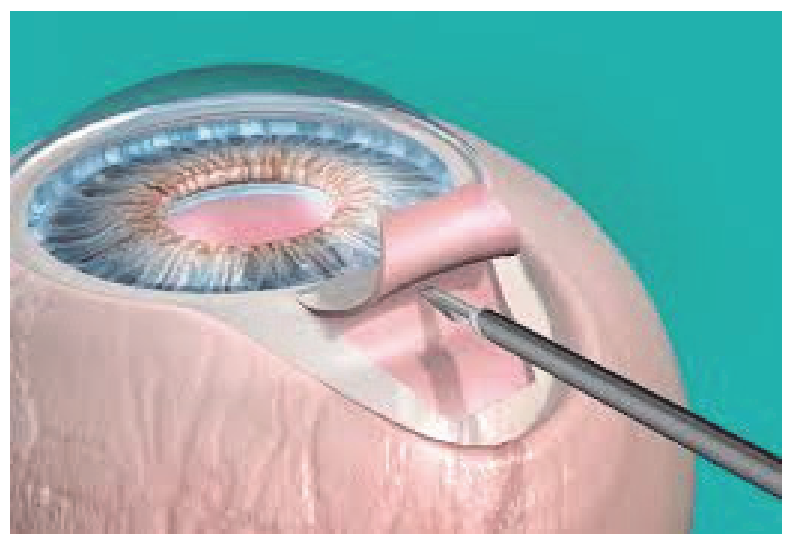

Slika 2.10. Trabekulektomija

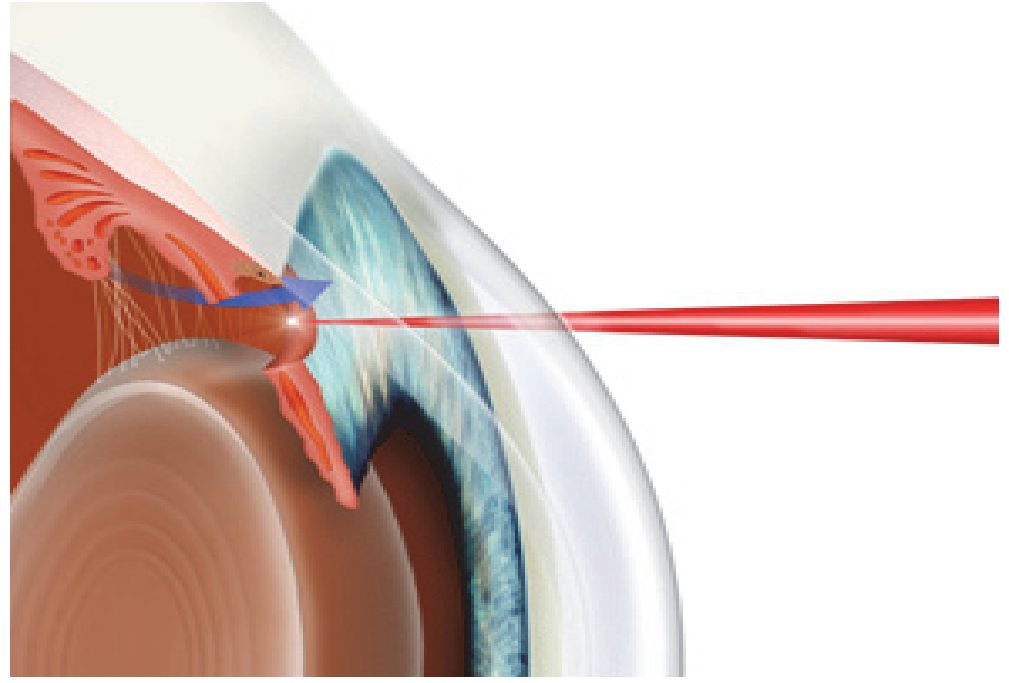

Slika 2.11. Iridektomija

Oba zahvata imaju za cilj omogućavanje isticanja očne vodice.

\section{Laserom se rade slijedeći zahvati:}

- Laserska trabekuloplastika ( stvaranje proaza kroz trabekulum),

- Laserska iridotomija ( stvaranje prolaza kroz iris ) i

- Gonioplastika ( korekcija deformacija sobičnog kuta ). 


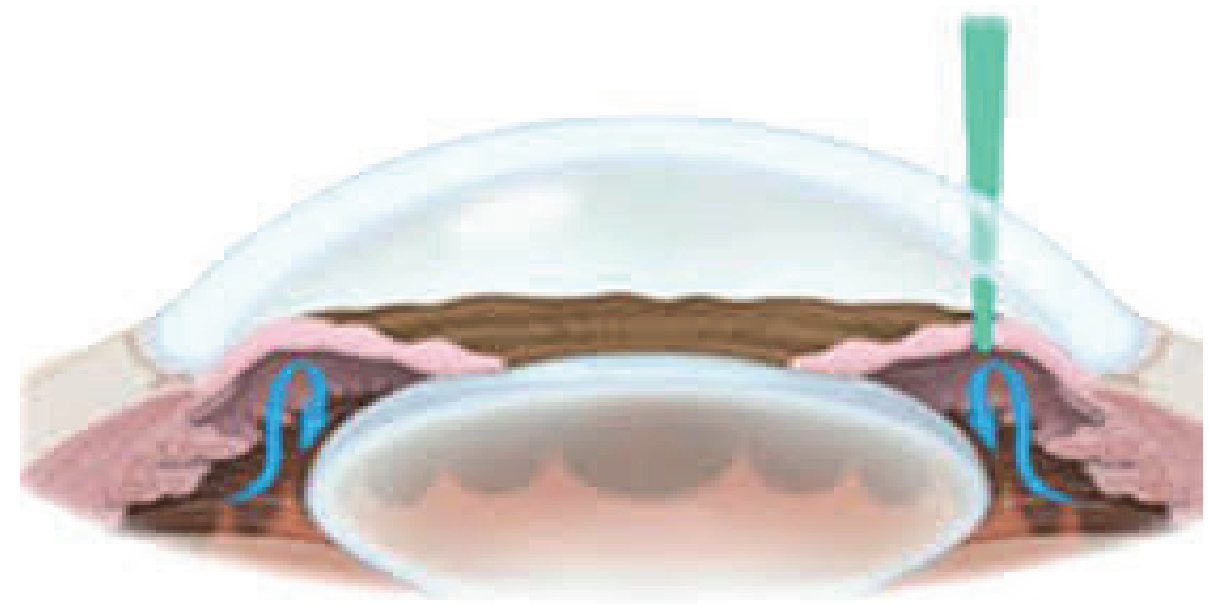

Slika 2.12. Laserska trabekuleplastika

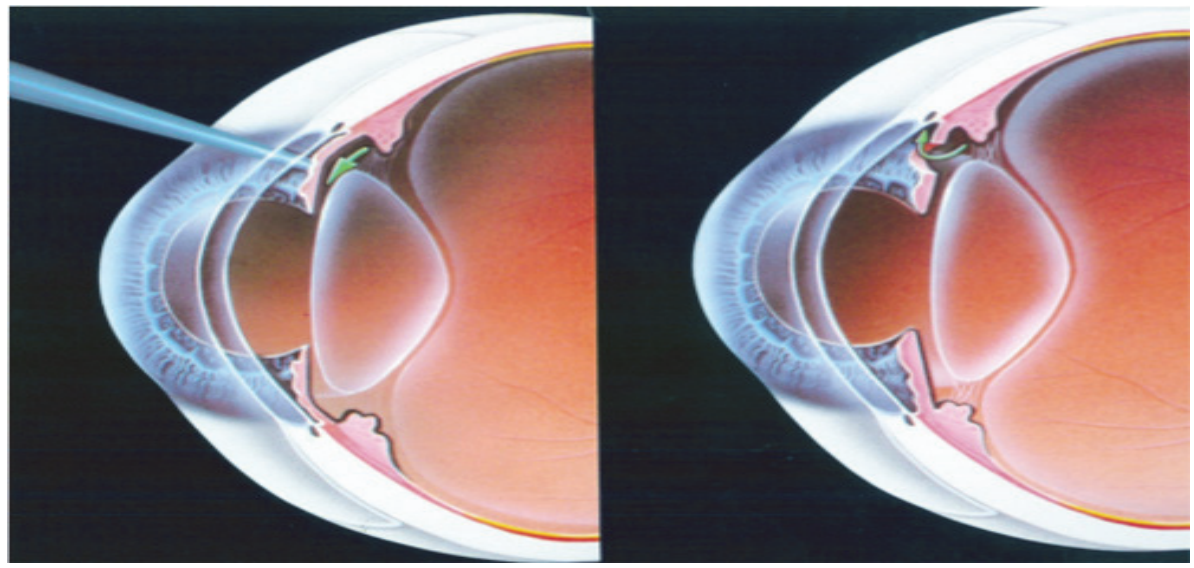

Slika 2.14. Laserska iridektomija

U rijetkim slučajevima u kojima ni hiruški zahvat ne da željene razultate, postoje metode liječenja koje se fokusiraju na uništavanje ćelija koje su odgovorne za prekomjerno lučenje tekućine u oku. To se može provesti ultrazvučnim liječenjem ( uništavanjem ćelija visokofrekventnim zvučnim valovima), diatermijom ( uništavanje ćelija visokom temeraturom ) ili pak kriokirurgijom ( uništavanje ćelija niskom temperaturom). 
Kod urođenog glaukoma je gotovo uvijek potreban hiruški zahvat. Ponekad se mogu koristiti lijekovi, no obično ne mogu pomoći na duži vremenski period.

Glaukom se ne može izliječii, no pritisak unutar oka može biti kontrolisan lijekovima, hiruškim zahvatom ili u kombinaciji te dvije metode. Kod odraslih, vid ili dio vidnog polja izgubljen kao posljedica glaukoma ne može se vratiti, ali se liječenjem može sprečiti daljnje oštećenje očnog živca i spasiti ostatak vida oboljele osobe. Kod neke djece koja pate od urođenog glaukoma, dio štete na očnom živcu može se popraviti hiruškim liječenjem.(17.18).

Lijekovi se, nakon postavljanja dijagnoze glaukoma, moraju u većini slučajeva uzimati do kraja života. Iako svakodnevno ukapavanje kapi nekim ljudima vjerojatno neće biti praktično ili može izazvati neugodu, izuzetno je važno pratiti upute liječnika o pravilnom ukapavanju u pravilnim vremenskim razmacima, kako bi se liječenje provodilo na ispravan način.(27).
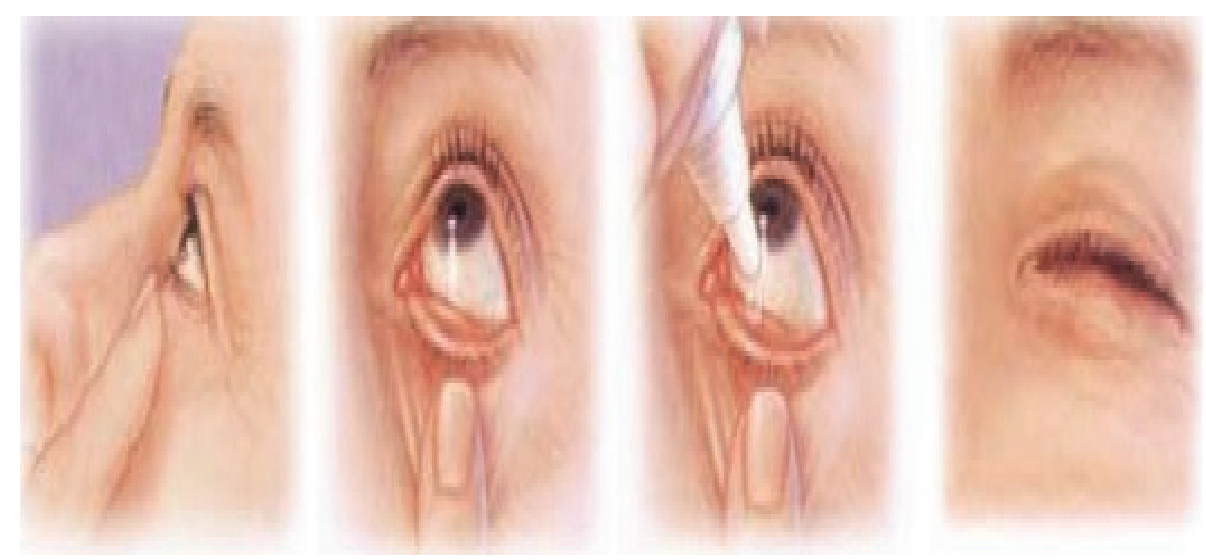

Slika 2.15. Kako pravilno koristiti očne kapi

\subsubsection{Prevencija glaukoma}

Najznačajniji faktori rizika su :

- Povišen očni tlak

- Povjest glaukoma u obitelji ( $20 \%$ vjerovatnosti glaukoma ako boluju roditeji, te $50 \%$ ako boluju brat ili sestra), 
- Dob ( $1 \%$ opće populacije u dobi od 40 do 49 godina, čak 20 do 30 $\%$ iznad 75 godina),

- Rasa ( tamnopute rase )

- Visoka kratkovidnost i dalekovidnost,

- Suspektni izgled vidnog živca, te tanja rožnica,

- Sistemske bolesti poput dijabetesa, hipertenzije, migrenozni glavobolja, Chronove bolesti, reumatoidnog artritisa itd.

- Nakon operacija oka ili produljenog kapanja kortikosteroidnih kapi,

- Bolovi oko očiju nakon gledanja televizije, te pojava duginih boja, tzv. haloa, oko rasvjete u noći.

- „Crne mrlje“ koje se pojavljuju na rubovima vidnog polja.

Budući da je većina faktora rizika za pojavu glaukoma izvan naše kontrole, prava prevencija protiv ove bolesti ne postoji. Preporučuje se starijim od 40 godina svakih 3 do 5 godina pregled oka koji obuhvata testove na glaukom po preporuci mnogih svjetskih stručnjaka koji se bave dijagnosticiranjem i liječenjem glaukoma.(27).

Ukoliko postoji povjest ove bolesti u obitelji ili ukoliko postoje faktori rizika od pojave glaukoma, neophodno je savjetovanje s oftalmologom o češćim pregledima oka.

\section{HIPOTEZA}

Cilj slijedeće studije je da se u što tačnijem broju prikažu dobijeni razultati, te da se prikaže broj oboljelih od glaukoma. Imamo dvije hipoteze: nultu i radnu.

Nulta hipoteza pokazuje jednakost kod svih dosadašnjih istraživanja učestalosti primarnog glaukoma kos stanovništva USK-a.

Radna hipoteza predstavlja negaciju nulte i njome ćemo pokušati dobiti druge razultate koji se razlikuju od do sada učinjenih istraživanja, te prezentirati svoje dobivene rezultate koje smo dobili svojim istraživanjem, a razlikuju se od do sada dobivenih rezultata kod stanovnika USK-a. 


\section{STATISTIČKA OBRADA PODATAKA}

Dobiveni podaci će biti statistički obrađeni pomoću statističkih testova za testiranje hipoteze. Podaci će biti unošeni u za to posebno kreirane tabele, to ćemo na osnovu podataka statističkom obradom doći di razultata istraživanja koristeći se sa Hi kvadrat testom i Studentovim T -testom.

\section{CILJEVI ISTRAŽIVANJA}

Cilj istraživanja bio je :

1. Prikazati učestalost i broj oboljelih od glaukoma na USK-a, u periodu 2008. do 2012. liječenih na Očnom odjelu Kantonalne bolnice „Dr. Irfan Ljubijankićc" u Bihaću, retrospektivnom studijom istraživanjapodatci koje smo dobili pri istraživanju učestalosti glaukoma u skrining studijama u navedenom periodu, a koje nismo do sada nigdje prezentirali.

2. Napraviti podjelu po dobnoj strukturi, i prikazati u kojoj dobnoj strukturi najčešće se javlja glaukom.

3. Prikazati učestalost oboljelih od glaukoma po spolnoj strukturi.

\section{MATERIJAL I METODE RADA}

Istraživanje je retrospektivnog karaktera. Obuhvaćen je broj oboljelih od glaukoma koji su liječeni u Kantonalnoj bolnici „, dr. Irfn ljubijankić“" u Bihaću u periodu od 2008 do 2012 godine, skrining studije u navedenom periodu.

Od materijala su mi poslužili:

- Protokol evidentiranih pacijenata Kantonalne bolnice „dr. Irfan Ljubijankić“" Očnog odjela u Bihaću za period od 2008 do 2012 godine.

- Zdravstveni kartoni povijesti bolesti i otpusna pisma pacijenata.

- Ostala medicinska dokumentacija. 


\section{RAZULTATI ISTRAŽIVANJA}

Tabela 6.1. Prikaz učestalosti glaukoma na području USK-a u periodu 2008. do 2012. godine na Očnom odjelu u Kantonalnoj bolnici „Dr. Irfan Ljubijankić u Bihaću.

\begin{tabular}{|c|c|c|c|c|c|c|c|c|c|c|}
\hline \multirow[b]{2}{*}{ 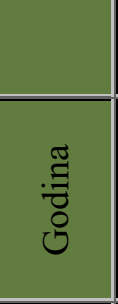 } & \multicolumn{8}{|c|}{ OPŠTINE UNSKO - SANSKOG KANTONA } & \multicolumn{2}{|c|}{ UKUPNO } \\
\hline & $\frac{\mathscr{U}}{\stackrel{U}{\Xi}}$ & తี & 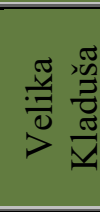 & 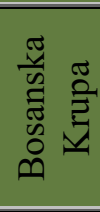 & 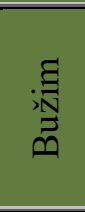 & 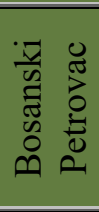 & $\stackrel{\text { 离 }}{\underline{\underline{Z}}}$ & 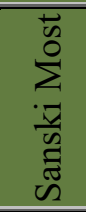 & $\begin{array}{l}Z \\
0 \\
\underline{\Xi} \\
\underline{\Xi}\end{array}$ & $\%$ \\
\hline $\begin{array}{c}2008 . \\
\text { god. }\end{array}$ & 18 & 15 & 11 & 8 & 5 & 1 & 6 & 13 & 77 & 15,06 \\
\hline $\begin{array}{c}2009 . \\
\text { god. }\end{array}$ & 23 & 20 & 15 & 10 & 7 & 2 & 5 & 16 & 98 & 19,17 \\
\hline $\begin{array}{c}2010 . \\
\text { god. }\end{array}$ & 26 & 21 & 17 & 10 & 6 & 2 & 7 & 15 & 104 & 20,35 \\
\hline $\begin{array}{c}2011 . \\
\text { god. }\end{array}$ & 29 & 26 & 20 & 12 & 8 & 3 & 7 & 19 & 124 & 24,26 \\
\hline $\begin{array}{c}2012 . \\
\text { god. }\end{array}$ & 25 & 22 & 17 & 11 & 6 & 3 & 8 & 16 & 108 & 21,13 \\
\hline Ukupno: & 121 & 104 & 80 & 51 & 32 & 11 & 33 & 79 & 511 & $100 \%$ \\
\hline$\%$ & 23,67 & 20,35 & 15,65 & 9,98 & 6,26 & 2,15 & 6,45 & 15,45 & $100 \%$ & \\
\hline
\end{tabular}

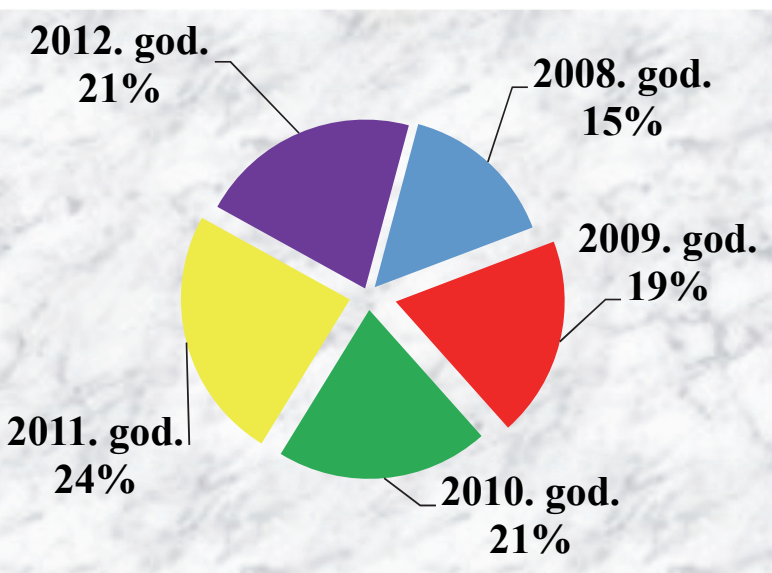

Grafinon 6.1. Učestalost glaukoma period od 2008. do 2012.godine. 


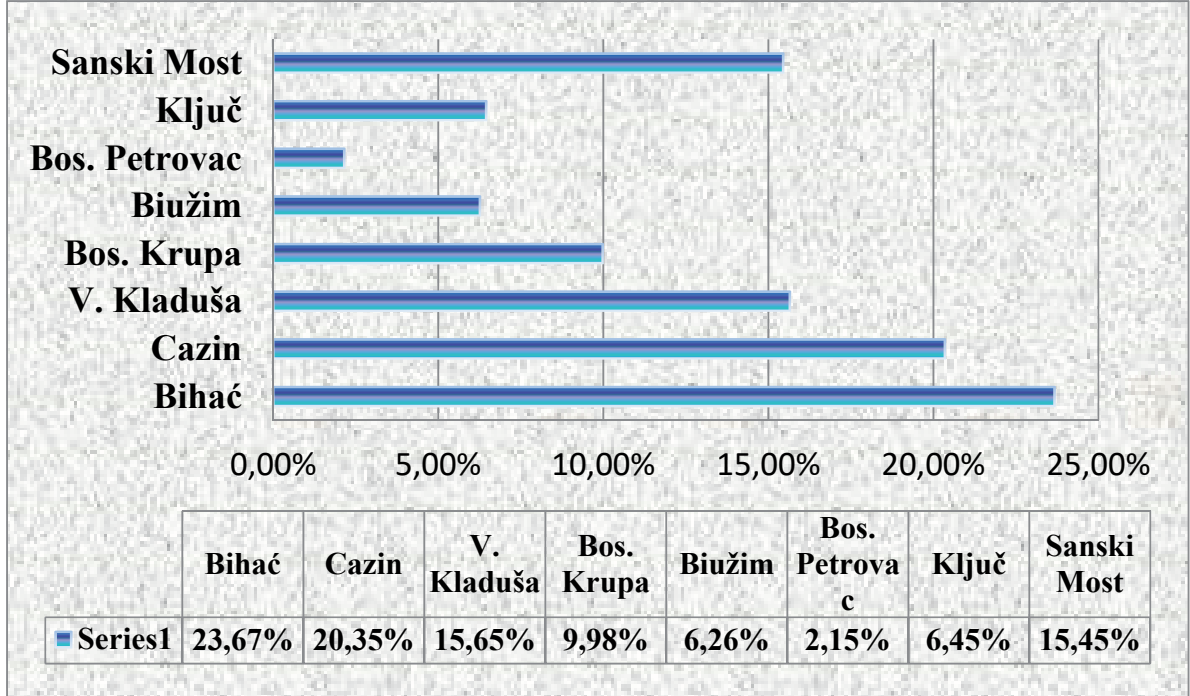

Grafikon 7.2. Prikaz stope glaukoma po općinama Unsko - sanskog kantona u periodu 2008. - 2012. godine.

Tabela 7.2. Podjela pacijenata po dobnoj strukturi i utjecaj starosne dobi na pojavu glaukoma u periodu od 2008. do 2012. godine na Očnom odjelu u Kantonalnoj bolnici „Dr. Irfan Ljubijankić“ u Bihaću.

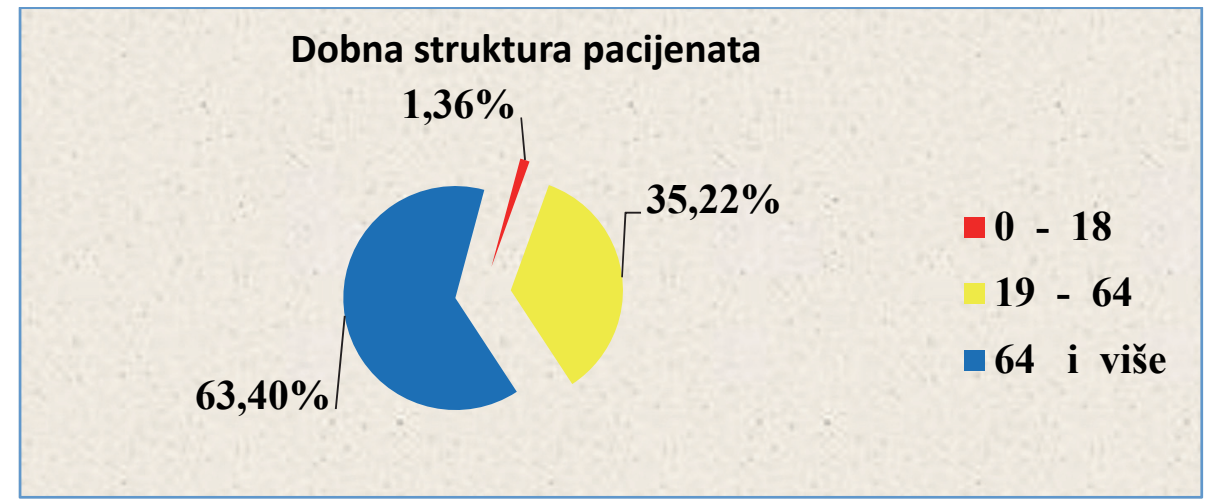

Grafikon 6.3. Prikaz dobne strukture pacijenata u periodu 2008 - 2012. godine. 
Tabela 6.3. Prikaz spolne strukture pacijenata oboljelih od glaukoma liječenih na Očnom odijelu Kantonalne bolnice „Dr. Irfan Ljubijankić“ u Bihaću

\begin{tabular}{|c|c|c|c|c|c|c|}
\hline \multirow[b]{3}{*}{ GODINA } & \multicolumn{4}{|c|}{ Spol pacijenta } & \multirow{2}{*}{\multicolumn{2}{|c|}{ UKUPNO }} \\
\hline & \multicolumn{2}{|c|}{ Muškarci } & \multicolumn{2}{|c|}{ Žene } & & \\
\hline & Broj & $\%$ & Broj & $\%$ & $\begin{array}{c}\text { Broj } \\
\text { pacijenata }\end{array}$ & $\%$ \\
\hline 2008.god. & 39 & & 38 & & 77 & 15,06 \\
\hline 2009.god. & 50 & & 48 & & 98 & 19,17 \\
\hline 2010.god. & 50 & & 54 & & 104 & 20,35 \\
\hline 2011.god. & 58 & & 66 & & 124 & 24,26 \\
\hline 2012.god. & 56 & & 52 & & 108 & 21,13 \\
\hline Ukupno: & 253 & & 258 & & 511 & $100 \%$ \\
\hline$\%$ & 49,51 & & 50,48 & & $100 \%$ & \\
\hline
\end{tabular}

\section{Spolna struktura pacijenata}

\section{$50,48 \%$}
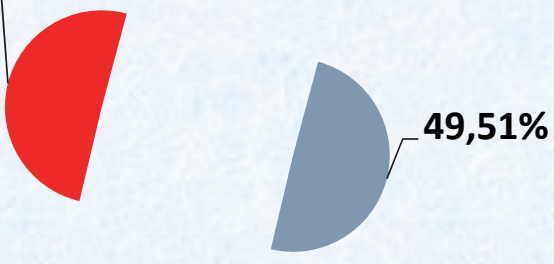

Muškarci

Žene

Grafikon 6.4. Prikaz spolne strukture pacijenatau periodu 2008 - 2012. godine

\section{DISKUSIJA}

Ukupan broj pacijenata odoljelih od glaukoma za dati vremenski period od 2008. do 2012. godine iznosi 511. Od toga najveći broj pacijenata susreće se u općini Bihać zabilježen je 121. pacijent odnosno 23,67 \%. na području općine Cazin evidentirana su 104. pacijenta odnosno 20,35\% .,a najniža stopa zabilježena je u opštini Bosanski Petrovac 2,15\%. odnosno 11 pacijenata. Moramo uzeti u obzir da su Bihać i Cazin najbrojnije opštine na našem kantonu.U odnosu na dobnu 
strukturu u posmatranom periodu od 5. godina možemo reći da se najveći broj oboljelih od glaukoma javlja u dobi preko 64. godine, njih je bilo 324. pacijenta odnosno 63,40 \%., zatim slijedi dobna struktura od 19. do 64. godine 180. pacijenata odnosno $35,22 \%$. i od 0 . do 18 . godina $1,36 \%$. odnosno 7 . pacijenata.Približno iste rezultate je dobio i Pelčić Goran, 2011, te Nada Čivčić u svojoj studiji 1989 na USK-a.

Dob i etničko porijeklo pacijenata kao i demografski faktori utječu na pojavu glaukoma.Mnoge studije pokazuju da dob ima glavni utjecaj na prevalenciju glaukoma koja se u opštoj populaciji kreće oko 2-3 \% kada je u pitanju pojava primarnog glaukoma u opštoj populaciji.Prema istraživanju mnogih autora učestalost glaukoma kod osoba starijih od 40 godina je oko 2 \% ( Peličić G.,2011,Čivčić N.,1983 ).U Baltimorskoj studiji zabilježena je prevalencija glaukoma u dobi od 40 do 49 godina u 1,23\% u Afroamerikanaca, 0,9 do $2 \%$ u bjelaca,a kod 11,26\% u Afroamerikanaca preko 80 godina.U populaciji azijskog porijekla najčešći je glaukom zatvorenog kuta ( Branimir Cerovski i saradnici.,Zagreb 2012 ).

U crnoj rasi je prevalencija glaukoma oko 4 puta veća ( Branimir Cervoski i saradnici.,2012 ).Genetska podloga glaukoma već je dugo u središtu interesa,jer je zapaženo da se glaukom češće javlja u osoba čiji su srodnici oboljeli od glaukoma.U monozigotnih blizanaca je učestalost glaukoma veća,nego kod dizigotnih,što potkrepljuje genetski koncept ( Peličić G.,2011 ).(28)

Ako uporedimo rezultate drugih autora i učestalost pojave glaukoma $\mathrm{u}$ opštoj populaciji USK-a u kojem živi oko 300000 stanovnika,te broj ispitanika dobijemo rezultate koji su prilično slični rezultatima drugih autora,tj; da je učestalost glaukoma na USK-a oko $2,5 \%$ dakle približno jednaka rezultatima drugih autora kada je u pitanju bijela rasa, pogotovo ako usporedimo rezultate istraživanja Nade Čivčić iz 1989 godine koja je dobila ičestalost glaukoma od 2,1\% kod stanovnoštva USK-a, dakle na istom području gdje smo i mi uradili naše istraživanje, što ukazuje da nije došlo do porasta učestalosti ovog oboljenja.(9).

Od 511. pregledanih pacijenta, 258 pacijenta bile su žene $(50,48 \%$.) , a 253 pacijenta bili su muškarci( 49,52 \%.). Kada je u pitanju spolna struktura približno iste rezultate je dobila i Nada Čivćić i989,odnos $\mathrm{M}: \breve{Z}=48,3 \%: 51,7 \%$ (9).Goran Pelčić,2011 godine nalazi da je taj odnos 
47,9\%:52,1\%, dalle bolest je nešto učestalija kod pacijenata ženskog spola.(28).

Istraživanjem su obuhvaćeni svi pacijenti u periodu od 2008. do 2012. godine pregledani na Očnom odijelu Kantonalne bolnice „Dr. Irfan Ljubijankić" u Bihaću.

\section{ZAKLJUČAK}

1. Programi SZO-a u sprječavanju sljepoće datiraju od sedamdesetih godina prošlog stoljeća. Podaci istraživanja kao što su npr. istraživanje Quingleya i Bromana trebali bi utjecati na planiranje zdravstvenih programa na globalnoj, ali na nacionalnoj razini.S obzirom na to da u razvijenim zemljama više od polovice bolesnika koji boluju od glaukoma nije svjesno svoje bolesti, možemo pretpostaviti da i na području našeg kantona postoji znatan broj nedijagnosticiranih glaukomskih bolesnika.

2. U odnosu na dob pacijenata ovim istraživanjem utvrđeno je da se glaukom najčešće javljao u dobi od 64.godine i više 324 odnosno 63,40 $\%$, a najmanja stopa zabilježena je u dobi do 18 godina $1,36 \%$ odnosno 7 pacijenata.(Pelčić G., istraživanjem u Primorsko-Goranskoj županiji je došao do približno istih rezultata kda je u pitanju dob pacijenata).

3. U odnosu na spol dokazano je da žene neznatno češće oboljevaju od glaukoma, njih 258 ili 50,48 \% u odnosu na muškarce 253 ili 49,52\%.(Kordić R., studija rađena na Očnoj klinici Rebro dobio je rezultate da je učestalost glaukoma kod žena $56,3 \%$ u odnosu na muške pacijente sa učastalošću od $43,7 \%$ ).Dakle naši rezultati bitno ne odudaraju od rezultata drugih autora.

4. Može se smatrati da je u prosjeku od glaukoma oboljelo oko 3\% cjelokupne populacije.Ako uzmemo u razmatranje samo stariju populaciju, taj broj je signifikantno veći.(Josef Flammer,Glaukom,Basel 2006).

5. Procjenjuje se da ima oko 70 miliona osoba u svijetu koje imaju značajne glaukomske promjene, ali samo polovina njih zna za bolest, a čak samo manji postotak prima adekvatnu terapiju i adekvatan tretman.

6. Stoga je i ovaj rad usmjeren na osvješćivanje šire medicinske populacije o teškim posljedicama glaukoma, kako na život svakog obo- 
ljelog pojedinca i njegove obitelji, tako i na socijalne i materijalne posljedice kao i na društvo u cjelini.

7. Prepoznavanje i rano liječenje glaukoma mora postati jedan od vodećih javnozdravstvenih programa u Bosni i Hercegovini.

8. Daljnji napori moraju se uložiti u edukaciju zdravstvenog osoblja općenito, naročito edukaciju liječnika primarne zdravstvene zaštite koji upućuju bolesnike na daljnju oftalmološku evaluaciju. Zdravstvenom politikom potrebno je omogućiti prosječnom građaninu dostupnu topičku terapiju, dostupnost redovite oftalmološke kontrole, kontinuirano odobravati specijalizaciju iz oftalmologije. Provođenjem javnozdravstvenih programa u smislu predavanja, članaka u tiskovima, promotivnih emisija $\mathrm{u}$ medijima $\mathrm{u}$ smislu propagacije mjerenja intraokularnog tlaka na javnim mjestima.

9. Bitno mjesto zauzima i ciljani probir onih bolesnika s faktorima rizika za razvoj glaukoma, kao što su povećani intraokularni tlak, starija životna dob, osobe s pozitivnom obiteljskom anamnezom za glaukom, osobe s niskim krvnim tlakom, osobe s visokom miopijom.

\section{LITERATURA}

1. Aasved H., Incidence of Glaucoma in Norway.Internacional kongres and Symposium Glaucoma, 21;29-33,Academic press, London 1980.

2. Alajbegović R., Primarni glaukom, Sarajevo, Grafičar, 1997.

3. Alajbegović R., Milanović Lj., Bijedić M., et al. Očne bolesti. Sarajevo.Svjetlost.1982.

4. Alice, T. Gasch, A.T., Wang P., Pasquale L.R., (2000): Determinants of Glaucoma Awareness in a General Eye Clinic. Ophthalmology, 107(2), 303-308.

5. Attebo, K., Mitchell, P., Cumming, R., Smith, W. (1997): Knowledge and beliefs about common eye diseases. Aust N Z J Ophthalmol., 25(4), 283-287.

6. Baker, H. (2008): Glaucoma Awareness. University College London, Institute of Ophthalmology. London

7. Baker, H., Cousens, S.N., Murdoch, S.N. (2009): Poor public health knowledge about glaucoma: fact or fiction? Eye, 1-5

8. Baker, H., Murdoch, I.E. (2004): Can a public health package on glaucoma reach its target population? Eye, 18, 478-482. 
9. Budimlić E. Oftalmologija.Univerzitetski udžbenik.Grafičar. Bihać,2008. godine.

10. Cerovski B. Oftalmologija.Univerzitetski udžbenik. Zagreb, 1995. Godine

11. Čivčić N., Oftalmološki arhiv,broj 12,1989.

12. Čustović K. Osnovna znanja iz oftalmologije. Sarajevo 2004. godine

13. Buys Y., Goldberg I., Lambrou G.N., Ritch R. (2008): World Glaucoma Day, 6 March 2008: tackling the glaucoma Pandemic. Acta Ophthalmologica, 86, 124-125.

14. Dandona, R., Dandona, L., John, McCarty, Rao (2001): Awareness of eye diseases in an urban population in southern India. Bulletin of the World Health Organization, 79 (2), 96-102.

15. Danesh-Meyer, H.V., Deva, N.C., Slight, C., Tan, Y.W., Tarr, K., Carroll, S.C., i sur. (2008): What do people with glaucoma know about their condition? A comparative cross-sectional incidence and prevalence survey. Clinical \& experimental ophthalmology, 36(1), 138.

16. European Glaucoma Society (2014): Terminology and Guidelines for Glaucoma. Savona: PubliComm. Feiner, L., Piltz-Seymour, J. (2003): Collaborative initial glaucoma treatment study: a summary of results to date. Curr Opin Ophthalmol 14, 106-111.

17. Gramer, G., Bernhard, H.F., Weber, F., Gramer, E. (2014): Results of a PatientDirected Survey on Frequency of Family History of Glaucoma in 2170 Patients. Invest Ophthalmol Vis Sci., 55, 259-264.

18. Grgec, J. (18. lipnja 2015). Sestrinstvo kbcsm.hr. Preuzeto 11. travnja 2016. iz Mrežnog odredišta http://sestrinstvo.kbcsm.hr/svjetski-tjedanglaukoma-2015-godine/

19. Hoevenaars J.G., Schouten J.S., van den Borne, B., Beckers, H.J., Webers, C.A. (2005): Knowledge base and preferred methods of obtaining knowledge of glaucoma patients. Eur J Ophthalmol., 15(1), 32-40. 53

20. Juzych, M.S., Randhawa, S., Shukairy, A., Kaushal, P., Gupta, A., Shalauta, N. (2008): Functional Health Literacy in Patients With Glaucoma in Urban Settings. Arch Ophthalmol., 126(5), 718-724.

21. 23

22. Kanski J.J.,Clinical Ophthalmology,1994.

23. Kozomara R.,Klinička Oftalmologija, Banja Luka, Glas srpski.2000. 
24. Krishnaiah, Kovai, Srinivas, Shamanna, Rao, Thomas (2005): Awareness of glaucoma in the rural population of Southern India. Community Ophtalmology, 53(3), 205-208.

25. Landers, J.A, Goldberg, I., Graham, S.L. (202): Factors affecting awareness and knowledge of glaucoma among patients presenting to an urban emergency department. Clinical \& experimental ophthalmology, 30(2), 104-9.

26. Lau, J.T.F., Lee, V., Fan, D., Lau., M., Michon, J. (2006): Knowledge about cataract, glaucoma, and age related macular degeneration in the Hong Kong Chinese population. The British Journal of Ophthalmology Livingston, P.M.,

27. Lee, S.E., De Paola, C., Carson, C.A., Guest, C.S., Taylor, H.R. (1995): Knowledge of glaucoma, and its relationship to self-care practices, in a population sample. Aust N Z J Ophthalmol., 23(1), 3741.

28. Mansouri, K., Orgul, S., Meier-Gibbons, F., Mermoud, A. (2006): Awareness about glaucoma and related eye health attitudes in Switzerland: a survey of the general public. Ophthalmologica, 220(2), 101-108.

29. Michielutte, R., Diseker, R.A., Stafford, C.L., Carr, P. (1984): Knowledge of diabetes and glaucoma in a rural North Carolina community.JCommunity Health,9(4), 269- 84.

30. Noertjojo, K., Maberley, D., Bassett, K., Courtright, P. (2006): Awareness of eye diseases and risk factors: identifying needs for health education and promotion in Canada. Canadian journal of ophthalmology. 41(5), 617-23.

31. Paulino Costa,V., Spaeth, G.L., Smith, M., Uddoh, C., Cabral Vasconcellos, J.P., Kara-José, N. (2006): Patient education in glaucoma: what do patients know about glaucoma? Arq Bras Oftalmol., 69(6), 923-927.

32. Pelčić, G., (2011): Glaukom kao javnozdravstveni problem. Medicina fluminensis, 47(3), 299-307. Pfeiffer, N., Krieglstein, G.K., Wellk, S. (2002): Knowledge about glaucoma in the unselected population: a German study. J Glaucoma, 11(5), 458-63.

33. Quigley, H. A., Brooman, A. T. (2006): The number of people with glaucoma worldwide in 2010 and 2020. Br J Ophthalmo, 90, 262-267. 54

34. Resnikoff, S., Pascolini, D., Etya'ale, D., Kocur, I., Pararajasegaram, R., Pokharel, G.P., Mariotti, S.P. (2004): Global data on visual 
impairment in the year 2002. Bulletin of the World Health Organization, 82(11), 844-851

35. Riad, S.: The Primary Care of Chronic Open Angle Glaucoma. Report to the Royal College Ophthalmologists. University College London Hospital.

36. Sefić.M. Budimlić E. Oftalmologija.Grafičar. Bihać 2002. godina

37. Sesar A. Nove dijagnostičke i terapiske mogućnosti na Klinici za očne bolesti Mostar novembar 2007. Godine

38. Šikić J. Oftalmologija.Medicinska knjiga. Zagreb 2003. godine

39. Tenkir, A., Solomon, B., Tenkir A.D. i sur. (2010): Glaucoma awareness among people attending ophtalmic outreach services in Southwestern Ethiopia. BMC Ophthalmology, 10:17

\section{WEB IZVORI}

40. http://hr.wikipedia.org/wiki/Glaukom

41. http://www.medicina.hr/clanci/glaukom.htm

42. http://www.ocni-centar.hr/EasyEdit/UserFiles/pdf/glaukom.pdf

43. http://www.vasezdravlje.com/izdanje/clanak/360/ 


\section{Budimlić E., Budimlić D., Budimlić A., Dedić H.}

University of Bihac

Faculty of health studies

enver.budimlic@gmail.com

Original scientific article

\section{SOCIAL-MEDICAL SIGNIFICANCE OF EARLY DETECTION PRIMARY GLAUCOMA IN CONSERVATION OF EYESIGHT AND PREVENTION OF BLINDNESS AS PERMANENT COMPLICATIONS}

\section{ABSTRACT}

For the life and work of a person, sight is of great importance, and the disability of the organs of vision takes a special place. Therefore, special attention should be paid to the prevention and early detection of visual disturbances that pose the potential causes of impairment. After the right to life, it follows the right of a man to look and see the world around him. Vision serves not only as a sense, but also as a possibility of communicating with the outside world. Glaucoma is an eye disease that causes damage to the optic nerve and may, if not treated to be resolved with total loss of vision. In ophthalmology, in addition to contemporary medical and surgical therapy, occupies a high place as a cause of weakness and blindness. According to the World Health Organization (WHO), glaucoma is at second place in the cause of blindness around the world and is a serious problem because visual impairment is irreversible.

Keywords: glaucoma, early diagnosis, prevention, therapy 


$$
\begin{aligned}
& \text { بودمليتش أ.، بودمليتش د.، بودمليتش آ.، داديتش هـ. } \\
& \text { جامعة بيهاتش بونش } \\
& \text { كلية الدراسات الصحية }
\end{aligned}
$$

الأهمية الاجتماعية-الطبية للكشف المبكرعن الجلوكوما (الماء الأزرق) الأولي في حفظ

$$
\text { البصروالوقاية من حدوث العهى كتعقيد دائم }
$$

\section{الخلاصة}

للبصر أهمية كبيرة في حياة الإنسان وعمله ولذك تتخذ إعاقة أعضاء الرؤية مكانًا

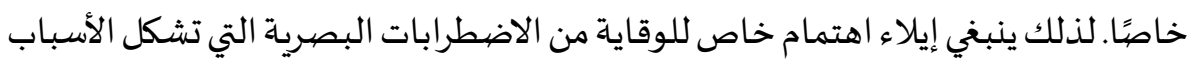
المحتملة لضعف البصر والكشف عنها في وقت مبكر.

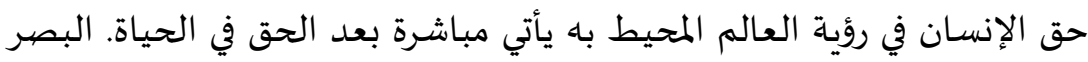

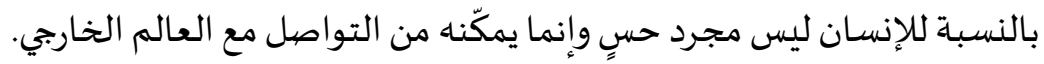

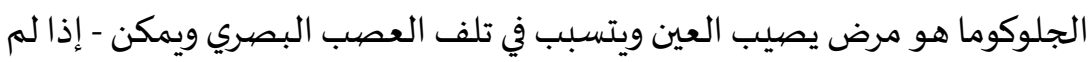
يتم علاجه - أن ينتهي بفقدان البصر، لذلك فإنها يحتل في طب العيون - على الرغم من

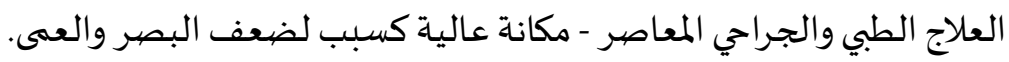

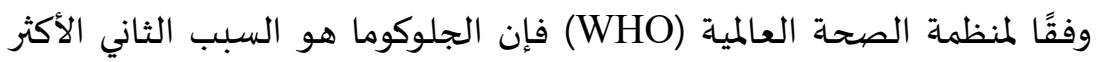

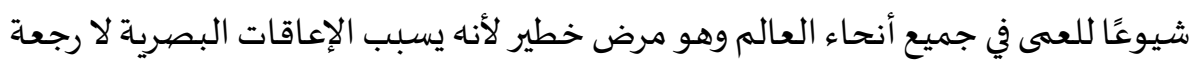
فيها. الكلمات المفتاحية: الجلوكوما، التشخيص المبكر، الوقاية، العلاج. 